\title{
SOCIOECONOMIC IMPACT OF MICROFINANCE ON BORROWERS: A CASE STUDY OF NRSP BANK MINCHANABAD
}

\author{
HAFIZ SAQIB MEHMOOD NAJMI \\ Ph. D. Scholar of Economics, \\ Superior University, Lahore, Pakistan. \\ FURRUKH BASHIR \\ Lecturer of Economics, \\ The Islamia University of Bahawalpur, Pakistan. \\ Bahawalnagar Campus \\ Email: farrukh.bashir@iub.edu.pk

\section{MUHAMMAD ZUBAIR ZIA} \\ M. Sc. Scholar of Economics, \\ The Islamia University of Bahawalpur, Pakistan. \\ Bahawalnagar Campus
}

\begin{abstract}
The present study investigates impact of Microfinance (NRSP Bank) on socioeconomic status of Borrowers living in Minchanabad District, Pakistan. For this purpose, primary data of 60 respondents is collected through Questionnaire using Stratified random sampling technique. The study concludes positive influence of Microfinance on income, health, education of children, living standards and businesses of borrowers. The problems faced by borrowers are high interest rate and difficult procedure to apply for a loan.
\end{abstract}

Keywords: Microfinance, Income, Health, Education, NRSP Bank, Primary Data, Minchanabad tehsil

JEL Classification Codes: C83, D31, I10, I20, Y10

\section{INTRODUCTION}

Microfinance is defined as the supply of loans and basic financial services to the poor according to a non-governmental organization namely The Consultative Group to Assist the Poor - CGAPi. Microfinance banks provides different financial facilities such as facility of loan, facility of insurance of business and health facility to the borrowers and it helps to overcome the vulnerable economic situation and also enable them to purchase assets. Such type of facilities is normally ignored by the commercial banks. According to 
the Brooks (2013), Microfinance is defined as the collection of financial services, including credit, advance and insurance cover, accessible by poverty stricken industrialists and small commercial proprietors who have no security and wouldn't otherwise meet the requirements for an average bank loan.

In many developing countries like Pakistan, maintenance of living standard of the people is crucial to the government. It is observed that enhancing income level can help them to raise their living standard. Microfinance is considered as one of the main factors for enhancing income of the people. Different organization at international level observed that there is miserable condition of people regarding poverty in developing countries. A large portion of population is living below the poverty line. Poverty has an adverse impact on overall economic situation of the country. There are currently three registered microfinance banks those are working in Minchanabad tehsil, Punjab, Pakistan. This area is also considered "Golden Sparrow" in the eyes of microfinance institutions. So, it is also important to know the impact of micro financing on socio-economic status of borrowers in this area.

This research addresses the role of microfinance in improving the socio-economic status of the borrowers and difficulties faced by the customers in getting loan. As introduction in first section, 2nd section describes about Microfinance Institutions, 3rd section presents the review from past studies internationally and nationally, forth section describes the data and methodological issues, fifth section explains the results of study based on descriptive statistics, sixth section concludes the study and gives some concluding remarks.

\section{MICROFINANCE INSTITUTIONS}

Microfinance Institutions are providing credit facilities to the borrowers for many decades which were neglected by the commercial banks. To provide loan to the people who have no collateral, the Irish Loan Fund System was started by Jonathan Swift in early 1700s. During the time period between 1950s and 1970s, donors and Governments focused on providing loan to the small farmers to enhance agriculture production. In South Asia, the microfinance movement was started in Bangladesh in 1970s to overcome poverty related problems. After the success of Microfinance plan in Bangladesh, the microfinance program was accelerated in India and other countries as well in the start of twenty first 
century. Grameen Bank of Bangladesh by Professor Muhammad Younus was the first person in the world who first invented the microfinance term by providing loan to the group of women during famine in Bangladesh in 1974. Moreover, he said that 5 percent of the people obtaining loans became out of poverty circle each year. The formal commercial bank ignored the small farmers or entrepreneurs because they had no security. So, in this way, microfinance is very helpful for these people. Now Microfinance is considered as one of the major factors to overcome the poverty level in the whole world. The outreach of Micro financing is increasing day by day in the world mainly in developing countries like Pakistan.

\section{Figure 1: Growth of Microfinance Industry}

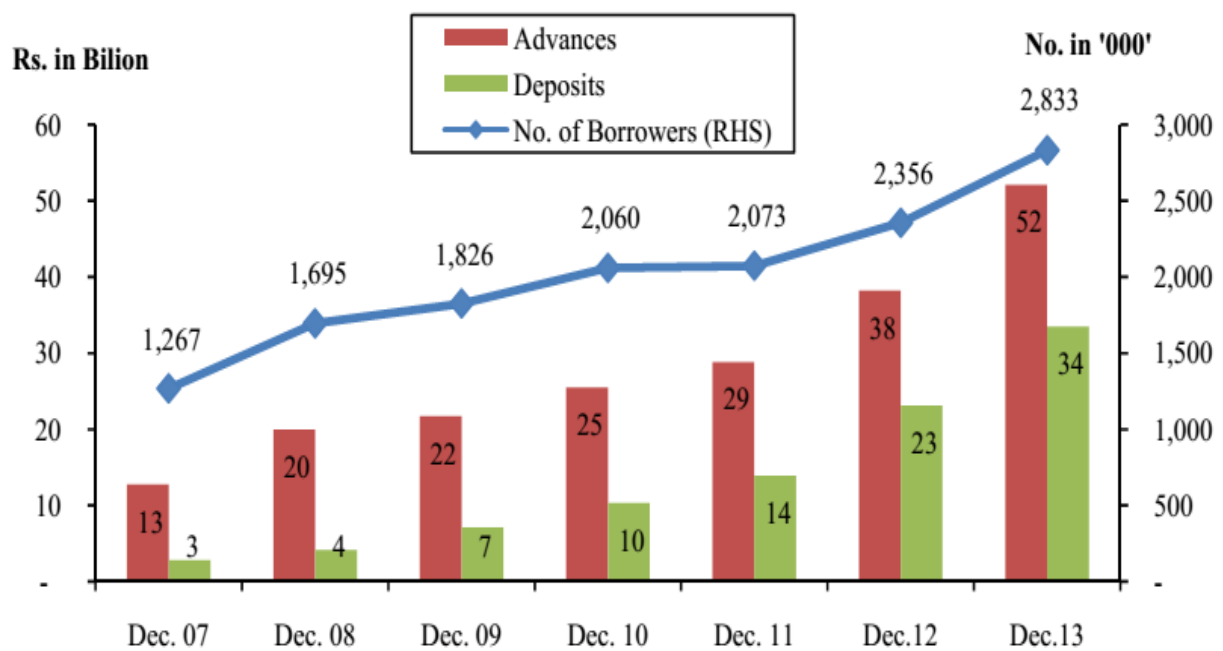

Source: Pakistan Economic Survey 2013 \& 14

Government of Pakistan along with Private Microfinance Institutions (MFIs) is providing the small and easy payable loan to small farmers or entrepreneurs. In Pakistan, the Microfinance got importance in late 1990s. Non Government Organizations (NGOs) are the base for specialized Microfinance institutions in Pakistan. After realizing positive role and need for microfinance as a important tool for poverty reduction, the government accelerated its efforts to build strong foundations for Microfinance. The major step in this way the government took was the launching of Microfinance Sector Development Program in 2000. The purpose of this program was to increase the pace of microfinance sector in the country and providing financial services to the poor. In 2000, the first Microfinance bank named as Khushali Bank was established. In 2001, the government of Pakistan passed the 
Microfinance Ordinance to provide separate regulatory framework for microfinance. According to Economic Survey of Pakistan (2013 -14), this sector is serving more than 2.8 million active borrowers in the country. The consistent growth was also observed in this sector during last decade.

In Minchanabad, there are three Microfinance institutions currently working i.e. (1) NRSP Bank Limited, (2) Khushali Bank and (3) FINCA Microfinance Limited. NRSP is considered as the leading bank among these banks as its customers are nearly about 7000 that are high from other two banks. Minchanabad is also considered as backward area in District Bahawalnagar. So it is important to reveal the impact of microfinance on borrowers.

National Rural Support Program (NRSP) was established in 1991 as Microfinance institution. It provides loan to poor sector of the society having no collateral security. It was registered as Not - for - profit organization under Section 42 of Companies Ordinance 1984. NRSP's main objective is to reduce poverty level in rural areas mainly.

NRSP Microfinance Bank Limited was established and started working in March 2011. It was intended to exchange the Micro Credit program of NRSP which was providing Pakistan's largest credit service to poor population into regulated Microfinance Banks to avail the benefits of the banking. NRSP is mainly concerned with agriculture loaning. But nowadays NRSP also provide livestock as well as small entrepreneur loan as well.

\section{LITERATURE REVIEW}

Different studies are conducted to evaluate the impact of microfinance on borrowers. This section presents a brief summary of related literature.

Ahmad et al. (2004) determined the effect of microfinance on declining rural poverty. This study was done to determine the impact of program of microfinance introduced by Khushhali Bank in District Rahim Yar Khan, Pakistan on poverty alleviation. For this purpose, data was taken from 100 borrowers of Khushhali Bank through scheduled interviews. The correlation analysis revealed that microfinance was positively associated with crop productivity, saving, income, farm expenditure and asset formation. The regression analysis also revealed similar results that micro credit had positive impact on income, saving, crop production, and farm expenditure. 
Javed et al. (2006) conducted study to determine the outcome of microfinance scheme launched by the NRSP on the socio-economic status of female community. To observe, data was collected from females who took loan. 100 females were chosen as sample by simple random sampling technique. The results found that this scheme of NRSP was serving best in female's community as 78 percent of the respondents stated that their income was increased after taking the loan.

Fayaz et al. (2006) conducted study to examine the impact of credit scheme launched by ZTBL on farmer's income and agricultural productivity. Data was taken from 80 respondents in which 40 were the beneficiaries and 40 were non beneficiaries. The results showed that income of beneficiaries of the credit scheme of the ZTBL was greater than non beneficiaries.

Shah et al. (2008) investigated the impacts of agriculture financing on farm productivity and farmer's income in District Chitral, Pakistan. The sample size was consisted of 112 respondents including 56 borrowers and 56 non borrowers. The results revealed that there was significant and positive association of credit with income and farm productivity of the farmers.

Saleem et al. (2010) determined the outcome of microfinance on the living status of poor people in District Dera Ismail Khan, Pakistan. Stratified random sampling technique was applied to get sample size of 50 respondents. The analysis found significant impact of microfinance on living condition of the people and also concluded positive impact of microfinance on education, financial condition and health status.

Mugabi (2010) explored the utilization of microcredit and its impact on income of the household in Iganga District, Eastern Uganda. A household survey was conducted to collect data through questionnaire. 120 respondents were selected as sample who took loan from microfinance institutions. Frequency distribution and percentile techniques were used for the analysis of data. The results revealed that microfinance played an important role in reducing poverty and enhancing the well-being of the borrowers.

Nouman et al. (2010) conducted study to check whether the services of microfinance were sufficient or not in rural areas of Khyber Pakhtunkhan, Pakistan. The sample size was consisted of 100 borrowers. The results showed insufficient services of 
microfinance available to the poors of Khyber Pakhtunkhan (KPK) which were adversely affecting the economic situation of the area.

Akram and Hussain (2011) ascertained the outcome of microfinance in raising living standard of the people by collecting data of 48 borrowers of Khushhali Bank Limited, Tameer Micro Finance Bank and The First Micro Finance Bank. The results showed positive impact of microfinance on living standard of the people as 85.40 percent of the people claimed that their living standard and income levels were increased after getting loan.

Mushtaq and Rauf (2011) conducted study to measure economic outcomes of micro credit on borrowers by using primary data collected from 200 respondents. The results showed positive impact of microfinance on borrower's well being.

Qureshi et al. (2012) determined the relationship between microfinance and its impact on poor borrowers. The research used primary data collected of 96 respondents through structured questionnaire, interviews and observation. The results showed that many people had no access to the microfinance due to lack of group security and high interest rate.

Khandker and Samad (2013) conducted study to determine role of microfinance in alleviating poverty in Bangladesh over the period of 20 years. Data was collected through different sources such as Credit and Development Forum and Household Income Expenditure Surveys conducted for 2000, 2005 and 2010. By applying econometric tools and descriptive statistics, the results revealed that micro credit enhanced income of the participants and consumption which helped to get rid of poverty level. It was also observed that participants involved in taking loan over 20 years were now in better economic situation.

Khan et al. (2013) conducted study to examine the performance of ZTBL on agriculture productivity in District Lakki Marwat, Pakistan. The data was collected from 100 respondents. The study explored that 12 percent of total beneficiaries used amount of credit on required purpose and remaining 88 percent used amount of loan other than required purpose. Their results also explained that there was no significant impact of credit on farmer's income and productivity. 
Ayuub (2013) observed the outcome of microfinance in reducing poverty level in Bahawalpur, Pakistan. The positive impact of microfinance on income level and living standard was observed with insufficient rise. High interest rate charged by the MFIs was also observed.

Hasan et al. (2013) examined the role of microfinance in agricultural output in Khulna District Bangladesh. The production of rice was taken as agricultural output because most of the farmers were involved in farming of rice in that area. The sample size was consisted of 80 respondents both borrowers and non borrowers. Data was collected through structured interviews by using both open-ended and close-ended questions. Descriptive and regression analysis were used and they observed the positive impact of microfinance on agricultural output. The study also observed that output of borrowers is 15 percent greater than as compared to the output of the non-borrowers.

Imoisi et al. (2014) determined the role of microfinance in alleviating poverty in Nigeria. The research used primary data collected through field survey from the borrowers of different microfinance institution in Edo State in Nigeria for the purpose. Chi-square statistics, percentages and pie charts were used for deriving results. The study found microfinance as playing significant role in reducing poverty as 70 percent of the respondents stated that their living standard was improved after taking loan.

Diro and Regasa (2014) conducted study to examine the relationship between livelihood of the borrowers and the micro credit. The basic purpose of their study was to find out the effect of micro credit service on the lives of the family members of the borrowers in Mekelle City of Ethiopia. For this rationale, primary data was taken from 287 clients and eligible non clients through semi-structured questionnaire. The results concluded that there was positive impact of micro credit on household income, consumption, and saving but no effect on employment of borrowers.

Alam et al. (2014) observed the role of microfinance on socio-economic status of borrowers. For this purpose, they collected data from the borrowers who got loan from Punjab Rural Support Program scheme in district Gujranwala, Pakistan. The sample size was consisted upon 185 borrowers collected through structured questionnaire. The results showed that microfinance played an important and significant role on socio-economic status of the farmers. Positive impact of microfinance on living standard of farmers such as children education, health status and diet pattern were also observed. 
Fareed et al. (2014) conducted study to check the role of microfinance in poverty alleviation. For this reason, the study collected data from 85 borrowers of Khushhali Bank Limited, First Microfinance Limited, Tameer Bank Limited and some others microfinance banks. The research observed positive role of microfinance on income level, saving and standard of living.

Rehman et al. (2014) investigated the relationship between agriculture credits on agriculture output. For deriving results, primary data was collected from 300 farmers through interviews. The results explained that agriculture production was positively and significantly associated with size of the household, income, education and long \& short term credit.

\section{DATA AND METHODOLOGY}

This section explains procedure for data collection and estimation approach to find out results of study.

\section{A. PROFILE OF STUDY AREA}

The present study is conducted in Minchanabad tehsil of District Bahawalnagar, Pakistan to evaluate the impact of Microfinance on socioeconomic status of borrowers. It is having an area of 1818 square kilometers. The climate of Minchanabad is usually hot and agricultural area. Its main crops include rice, wheat, cotton and sugarcane. Two canals are passing through Minchanabad i.e. Sadqia and Fordwa canal. There also exist two major industries of rice and oil.

According to Punjab Development Statistics 2013ii, it has 20 union councils in which three union councils are urban and seventeen are rural union councils. According to the estimation of Punjab Bureau of statistics as on $31^{\text {st }}$ December 2013, the population of Minchanabad was consisted of 470,000 people in which urban population is 49000 and rural population is 421000 . There is one government hospital of forty beds. There are five dispensaries and eighteen Basic Health Units. There are 510 schools including public and private sectors. There are 3 boys Colleges and 2 girls Colleges and 2 vocational training institutes.

Multiple Indicator Cluster Surveyiii (MICS) 2007 \& 2008 provide the tehsil-wise poverty situation in all districts of Punjab. The survey showed that in Minchanabad, there 
was more vulnerable conditions of poverty as compared to the others tehsils of the district. Figure 2 shows the poverty situation in District Bahawalnagar.

\section{Figure 2: Poverty Headcount Ratio of District Bahawalnagar}

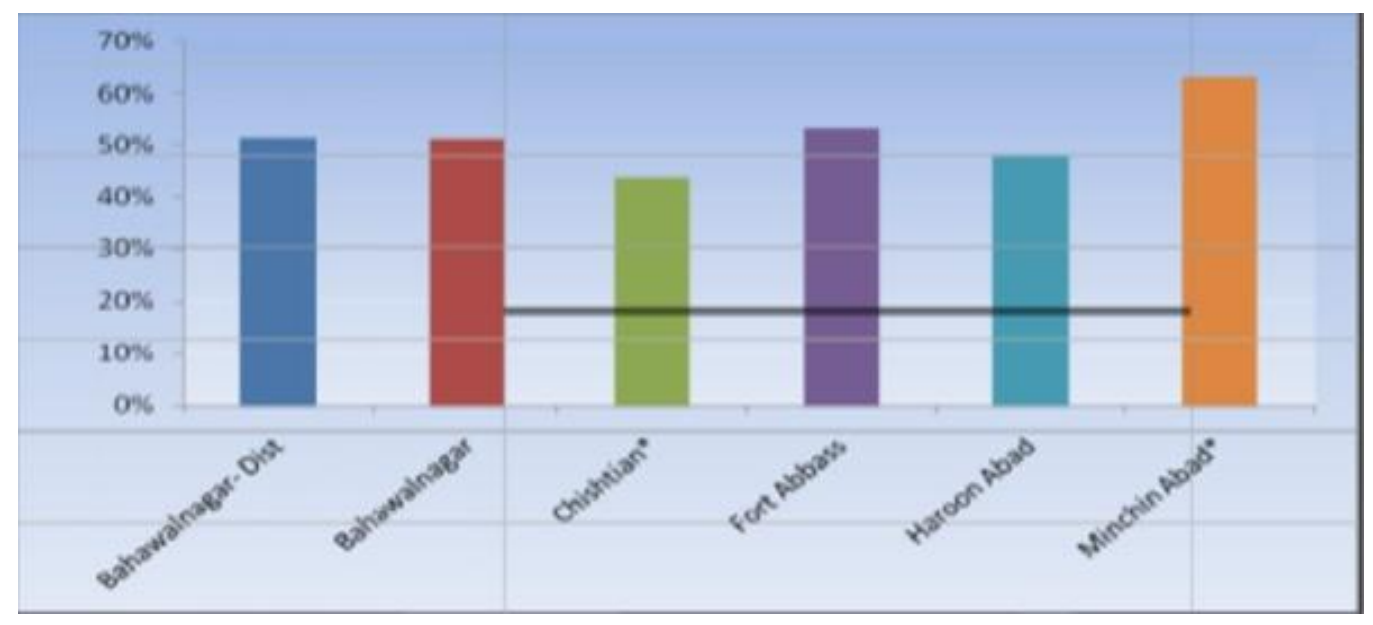

Data Source: Punjab Bureau of Statistics:

\section{B. SAMPLE SIZE AND ESTIMATION}

The sample size is consisted on 60 borrowers of the NRSP Bank in Minchanabad tehsil. Stratified random sampling technique is used to select the sample for this study. There are 5 ROs (Relationship Officer) working in Minchanabad Branch of NRSP Bank. All the clients of NRSP bank are already divided into groups of 5 ROs. Therefore 12 borrowers are selected from each $\mathrm{RO}$. The rationale behind choosing this sampling technique is that it provides greater precision than using the simple random technique of the same size. This sampling technique also requires less sample size which saves time and money. The analysis of data is based on percentages and frequency distribution using SPSS 21. The results are presented using bar charts.

A close ended structured questionnaire is developed for the collection of data. A field survey was conducted for the collection of data. Before conducting the survey to collect the data, permission was taken from the bank manager. For avoiding biasness in responses, each respondent is visited separately. As most of our respondents did not know reading and writing, that's why researcher conducted face to face interviews to fill the questionnaires. 


\section{LIMITATIONS}

Due to cost \& time constraint, the sample size for this study is consisted on 60 borrowers who took loan from NRSP Bank. By increasing the sample size, the results would be more reliable and more significant. Similarly increasing the population of this study would also give better picture of Microfinance. This study is conducted only in one tehsil of District Bahawalnagar. So conducting study in all tehsils of Bahawalnagar would give more significant results.

\section{RESULTS AND DISCUSSION}

\section{A. DESCRIPTION ABOUT RESPONDENTS}

This study carries out few features of socio-economic status including education, occupation, gender, age, marital status and major source of income of the respondents as displayed in Table 1.

Table 1: Demographic Characteristics of Borrowers

\begin{tabular}{|c|c|c|c|}
\hline Features & Categories & Frequency & Percent \\
\hline \multirow{6}{*}{ Education } & Illiterate & 27 & 45.0 \\
\hline & Primary & 23 & 38.3 \\
\hline & Middle & 2 & 3.3 \\
\hline & Metric & 6 & 10.0 \\
\hline & Inter & None & None \\
\hline & B.A. or More & 2 & 3.3 \\
\hline \multirow{2}{*}{ Occupation } & Agriculture & 53 & 88.3 \\
\hline & Business & 7 & 11.7 \\
\hline \multirow{2}{*}{ Gender } & Male & 47 & 78.3 \\
\hline & Female & 13 & 21.7 \\
\hline \multirow{4}{*}{ Age } & $20-30$ & 10 & 16.7 \\
\hline & $31-40$ & 23 & 38.3 \\
\hline & $41-50$ & 21 & 35.0 \\
\hline & 50 or More & 6 & 10.0 \\
\hline \multirow{2}{*}{ Marital Status } & Unmarried & 5 & 8.3 \\
\hline & Married & 55 & 91.7 \\
\hline \multirow{3}{*}{$\begin{array}{l}\text { Major Source } \\
\text { of Income }\end{array}$} & Agriculture & 52 & 86.7 \\
\hline & Farming & 1 & 1.7 \\
\hline & Livestock & 7 & 11.7 \\
\hline
\end{tabular}

From the above table, it may be concluded that most of the borrowers are illiterate or having Primary level of education. As 45 percent of the borrowers are illiterate and 38.3 percent are Primary educated and only 3.3 percent are graduated or above. By occupation, 88.3 percent of our respondents are engaged in agricultural activities. There are 78.3 
percent male and 21.7 percent females borrowers in the sample. Most of the respondents are under the age of 31 to 50 years as the percentage of these respondents is 73.3 percent while 86.7 percent of our respondents claim that their major source of income is agriculture.

\section{B. GRAPHICAL ANALYSIS}

The figures shown in this section demonstrate the impact of microfinance on socioeconomic status of borrowers as well as highlight some problems faced by the borrowers in getting loan.

\section{AMOUNT OF LOAN}

Most of the respondents took Rs. 25000 as a loan (45 percent of the total) from bank and 20 percent respondents took Rs. 30000 and 31.7 percent took More than Rs. 30000 . Only 3.4 percent of our respondents took below Rs. 25000 . Majority of the clients of NRSP bank took loan between the amounts Rs. 25000 to Rs. 30000 .

\section{Figure 3: Amount of loan}

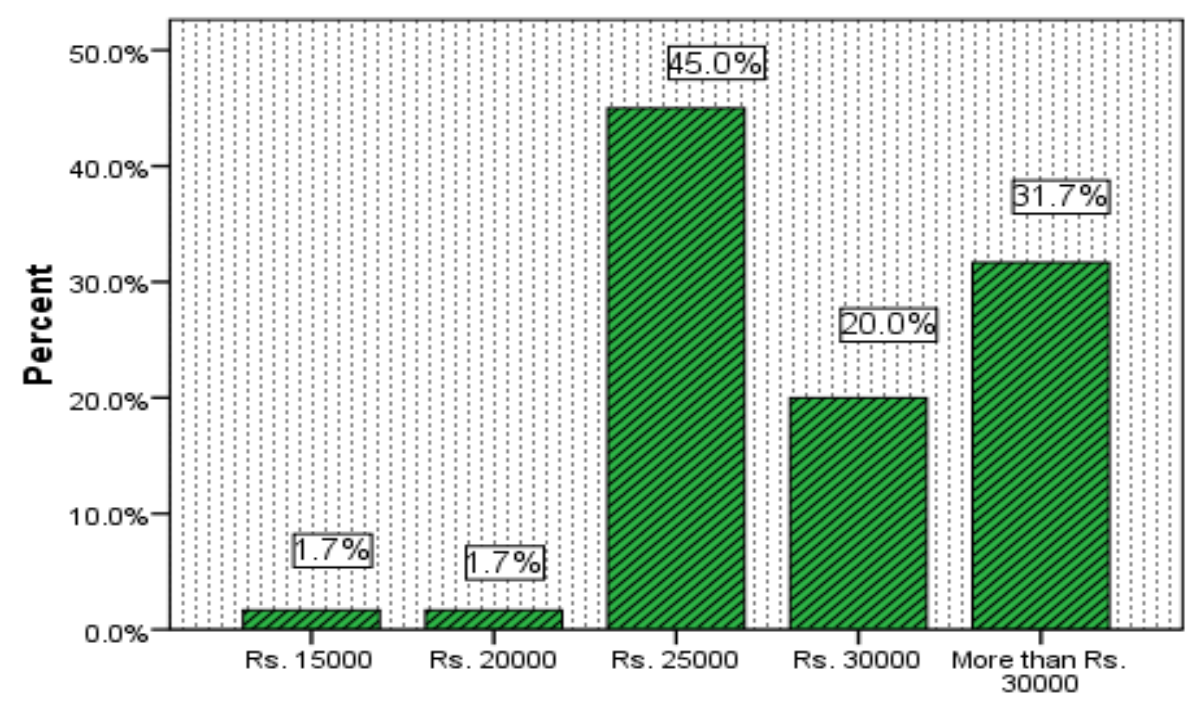

\section{PURPOSE OF LOAN}

Most of the people who took loan from Microfinance institutions invested in agriculture, small business and livestock etc. The above graph shows that 88.3 percent of respondents invested the amount of loan in agriculture such as purchase of fertilizers and seeds. Only 11.7 percent of respondents invested in small enterprises. It is due to the fact that major function of NRSP is agricultural loaning. 
Figure 4: Purpose of Loan

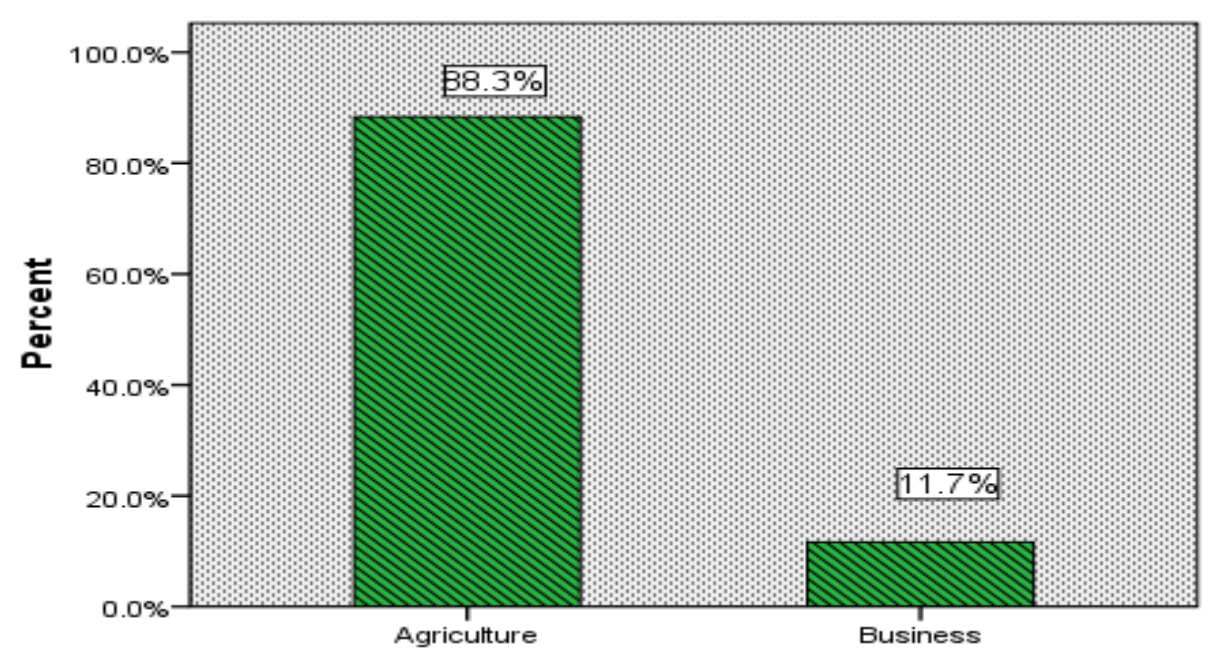

DID BANK LEND YOU SUFFICIENT AMOUNT OF LOAN?

56.67 percent of respondents declared that the amount of loan was not sufficient as most of the clients received just Rs. 25000 to 30000 as loan.

Figure 5: Did Bank lend you sufficient amount of loan?

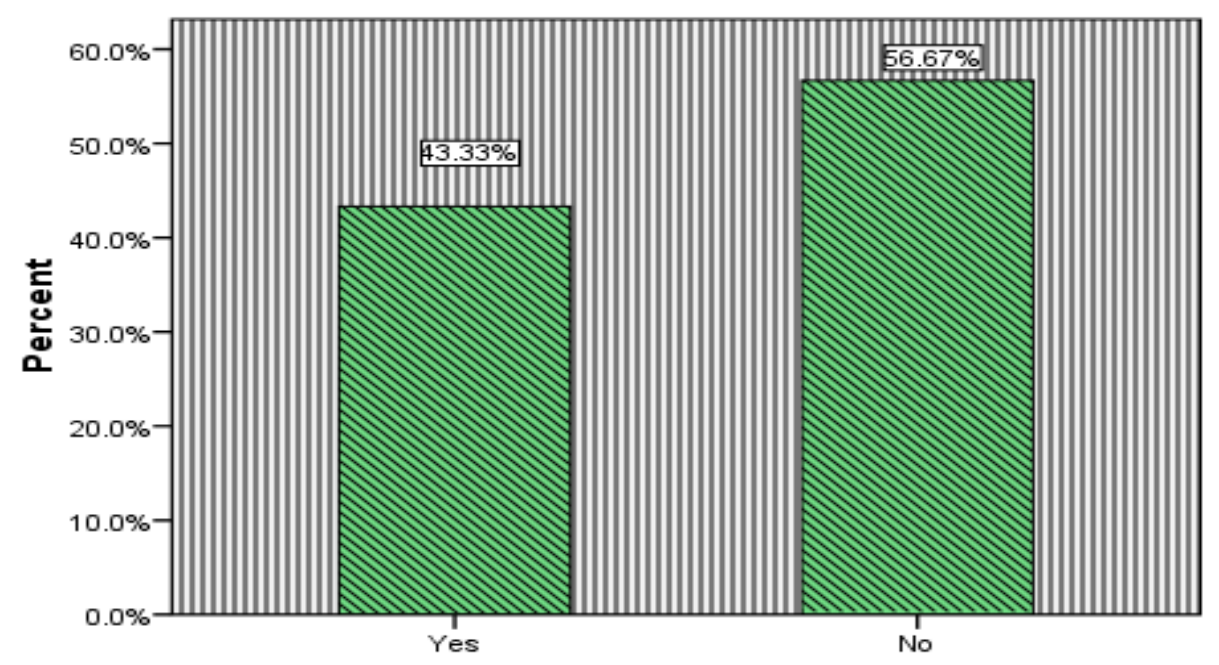

\section{HOW MANY DAYS DID BANK TAKE TO GIVE LOAN?}

75 percent of the respondents stated that they received the amount of loan after 10 or more than 10 days while only 3.3 percent reported that they received the amount of loan within 4 or 5 days. 5 percent and 16.7 percent of respondents received the amount of loan within 6 to 7 days and 8 to 9 days respectively. 
Figure 6: How many days did bank take to give loan?

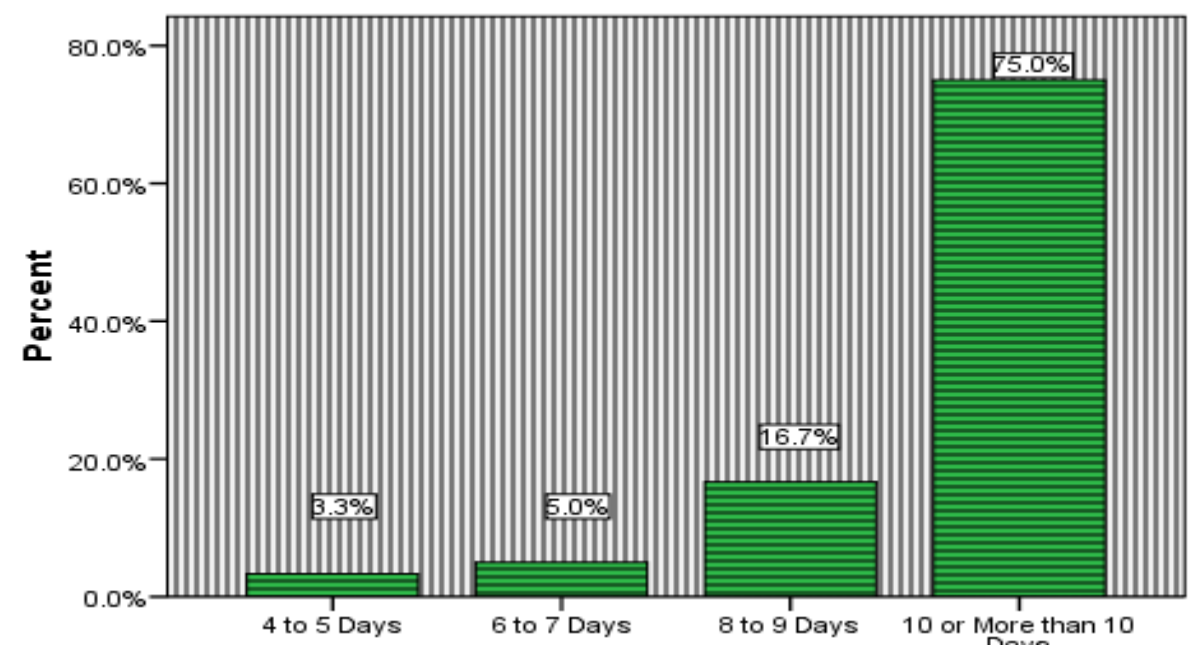

WAS THERE ANY INCREASE IN INCOME AFTER UTILIZING OF LOAN?

A significant increase in the income of respondents (83.3 percent) was noticed after utilization of loan while only 16.7 percent asserted no change in income.

Figure 7: Was there any increase in income after utilizing of loan?

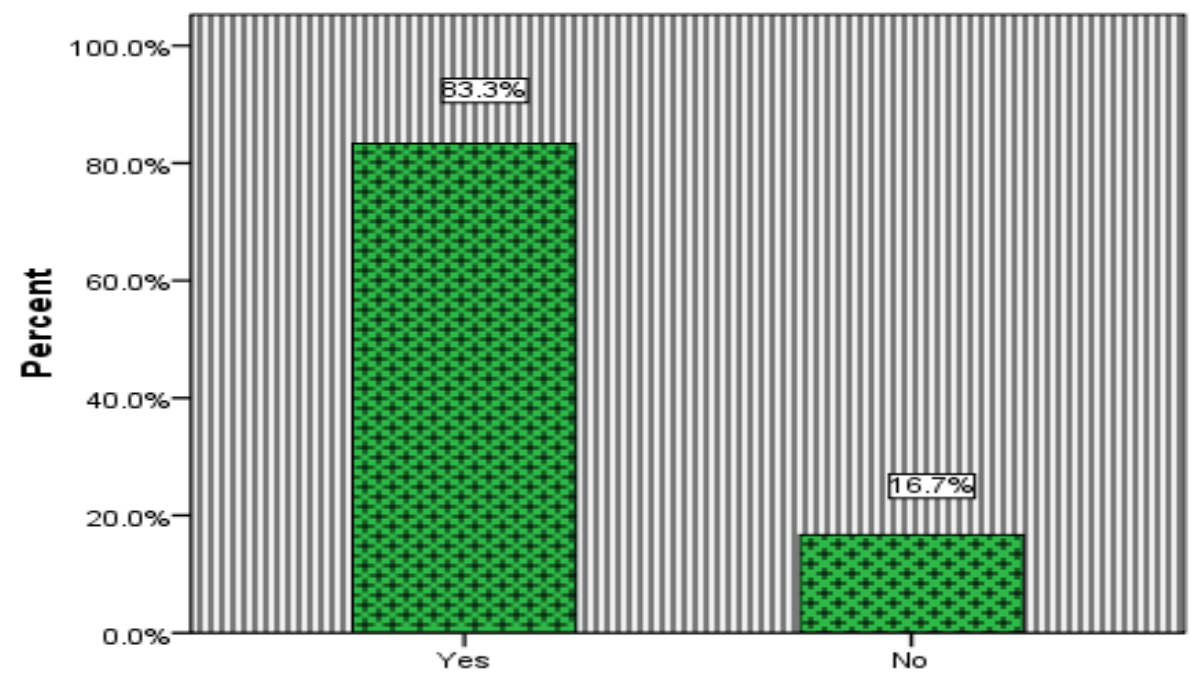

WAS INCREASE IN INCOME ENABLING YOU TO PURCHASE ANY ASSET?

According to 84 percent respondents, increase in income did not enable them to purchase any kind of asset such as land, house, household items, business and agricultural input etc but only 16 percent borrowers could purchase agricultural equipments. 
Figure 8: Was increase in income enabling you to purchase any asset?

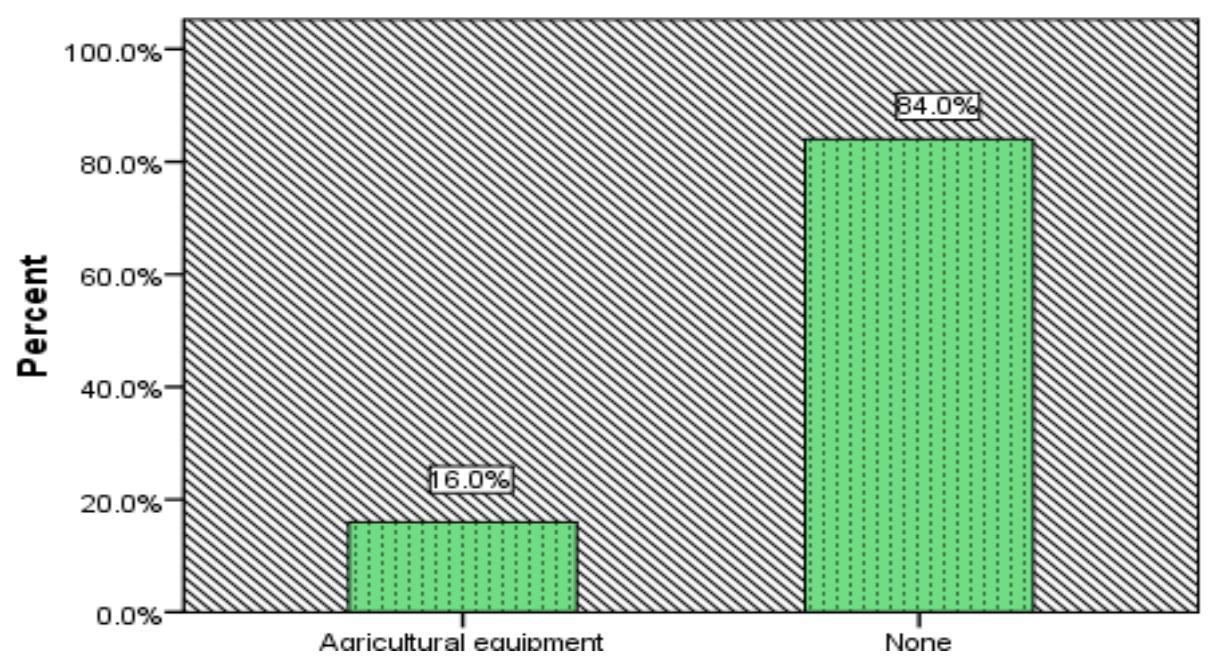

WAS THERE ANY POSITIVE CHANGE IN HEALTH STATUS AFTER UTILIZATION OF LOAN?

51.67 percent of respondents confirmed that their health status became better after utilization of amount of loan while 48.33 percent respondents affirmed opposite.

Figure 9: Was there any positive change in health status after utilization of loan?

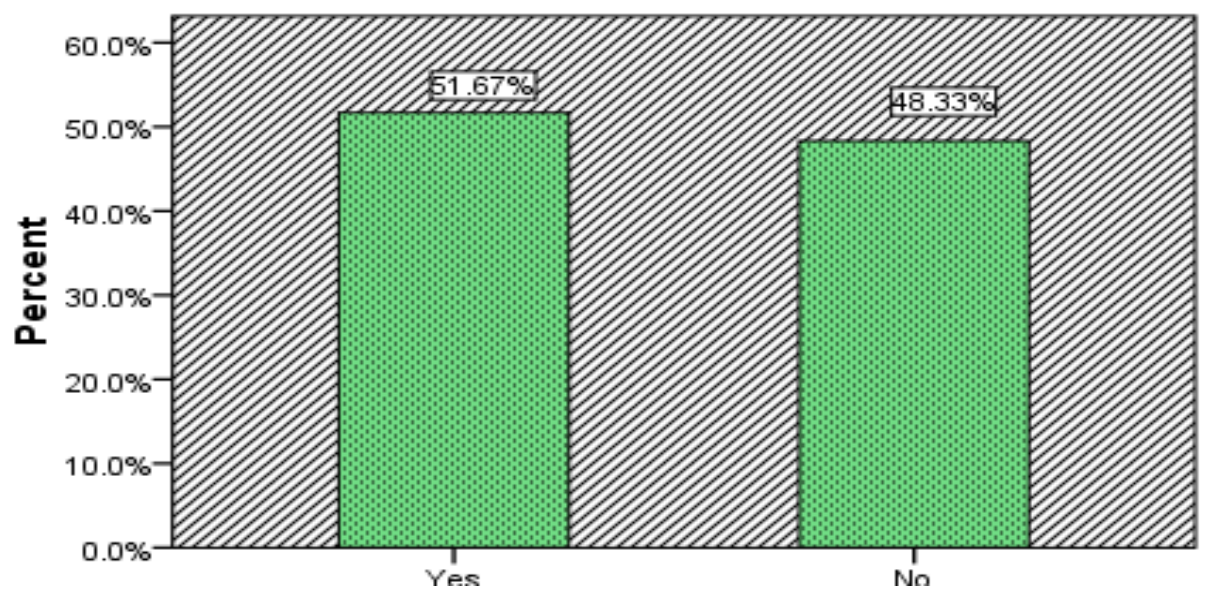

DID THIS LOAN HELP YOU TO PROVIDE BETTER EDUCATED TO YOUR CHILDREN?

53.45 percent respondents were providing better education to their children after utilization of loan while 46.55 percent respondents proclaimed no impact of loan on their children education. 
Figure 10: Did this loan help you to provide better educated to your children?

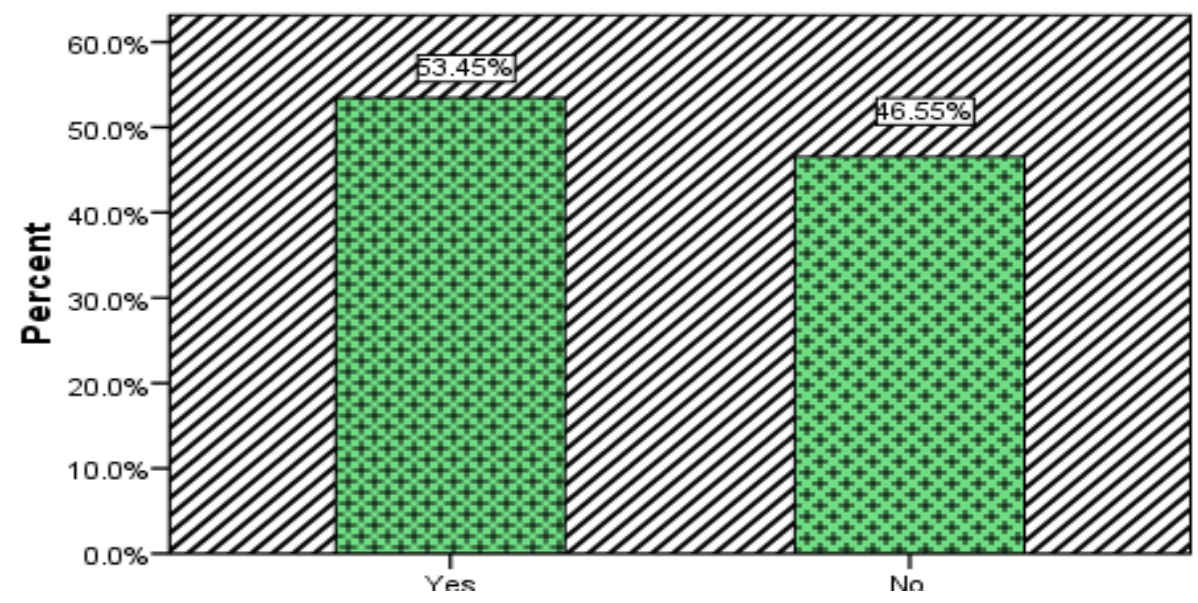

WAS THE BUSINESS EXPANDED AFTER UTILIZATION OF CREDIT?

Business of 70 percent respondents increased after utilization of credit but 30 percent respondents reported in opposite sense.

Figure 11: Was the business expanded after utilization of credit?

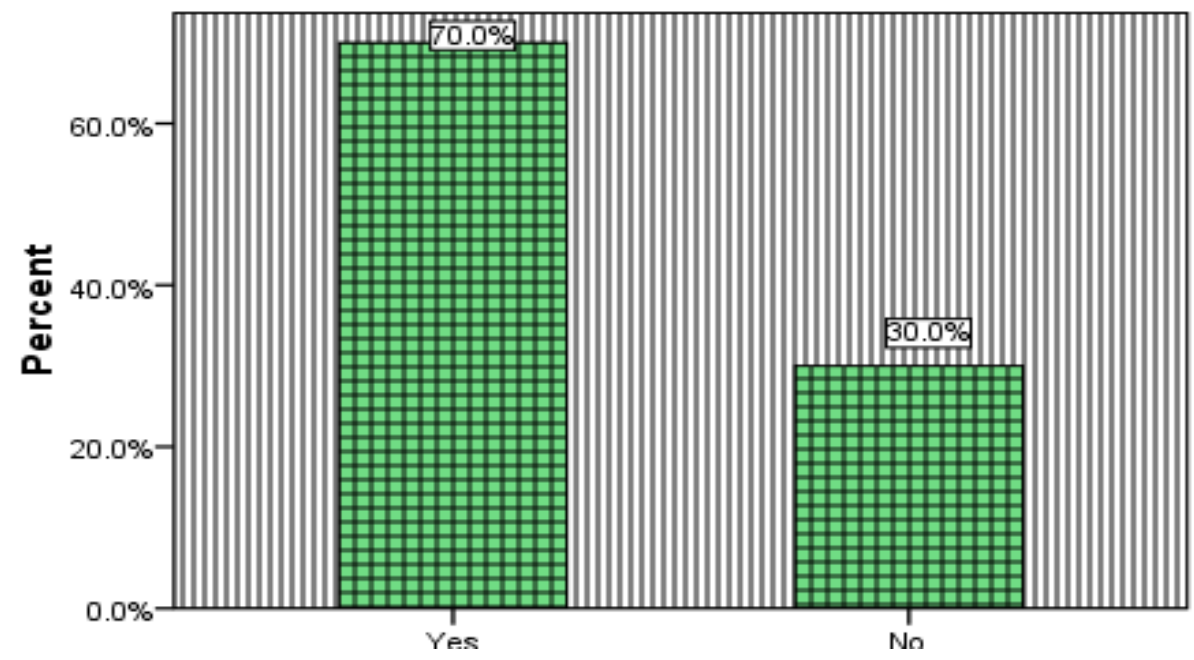

HOW MANY WORKERS DID YOU EMPLOY AFTER EXPANDING BUSINESS?

65.9 percent respondents said that they did not hire any worker, 25 percent respondents hired one additional worker and no one reported that they became able to hire more than three workers in their businesses after expansion. The reason is that the expansion in business is not so large and the amount of loan was also not so large that businesses may be expanded at large scale. 
Figure 12: How many workers did you employ after expanding business?

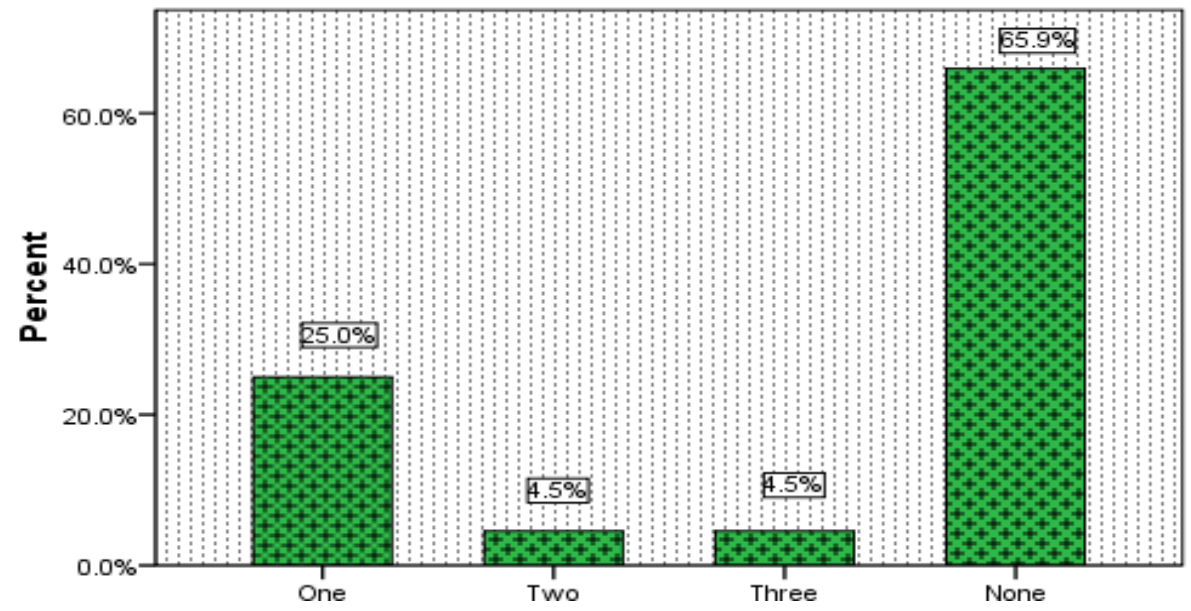

OPINION ABOUT INTEREST RATE CHARGED

No any respondent reported that the interest was low. 60 percent respondents stated interest rate charged by the bank to be high or very high while only 40 percent revealed interest rate to be affordable.

Figure 13: Opinion about interest rate charged

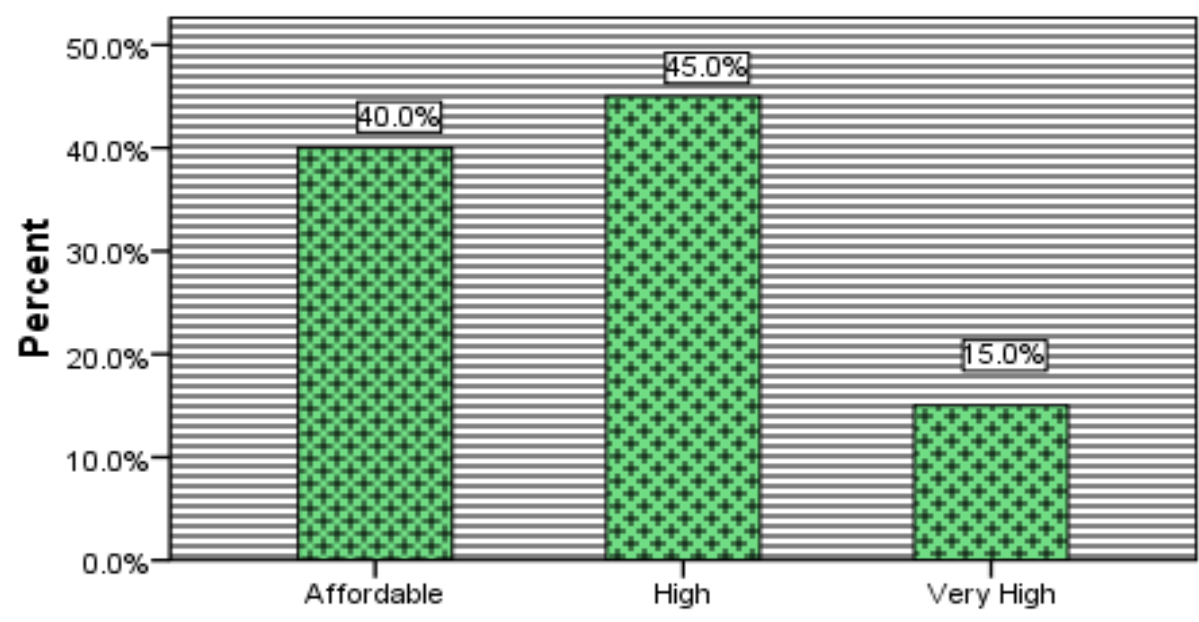

ANY IMPROVEMENT IN LIVING STANDARD

2.17 percent respondents felt very much improvement in their living standards, 50 percent were of the opinion of more advancement in living standards. In opinion of 41.30 percent respondents, there was less improvement while least progress in living standard was observed by 6.52 percent 
Figure 14: Any improvement in living standard

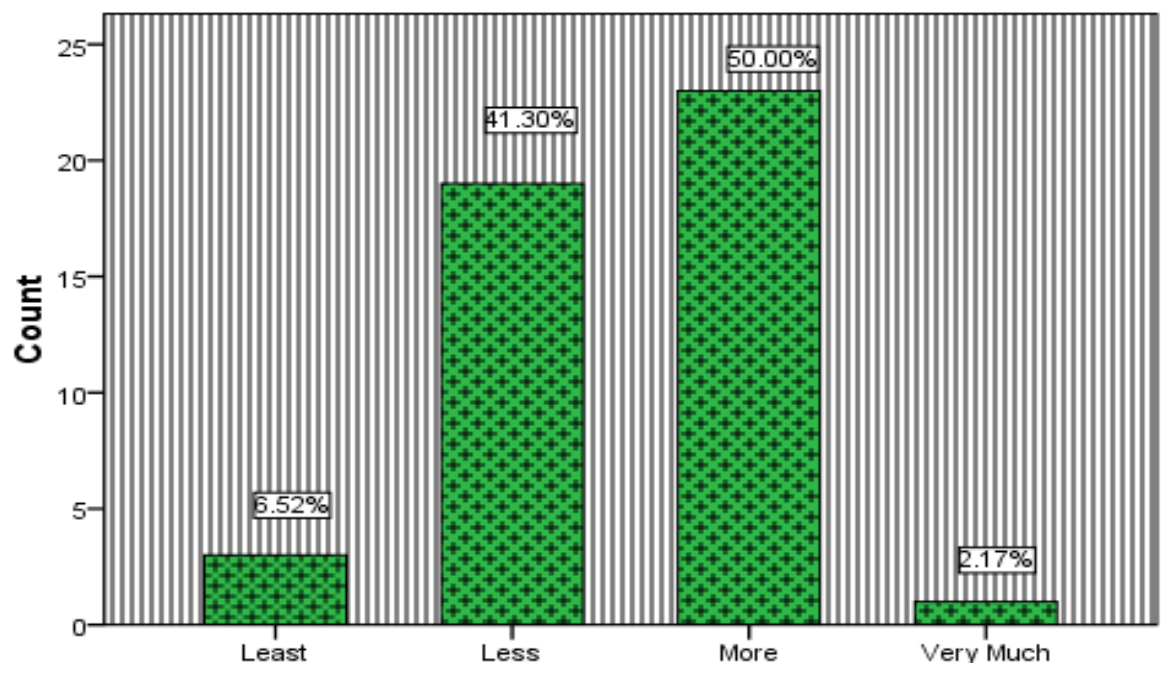

RATING THE BANK

Most of respondents (more than 58.3 percent) were much satisfied with communication of bank, while few respondents were dissatisfied from the NRSP bank.

\section{Figure 15: Rating the Bank}

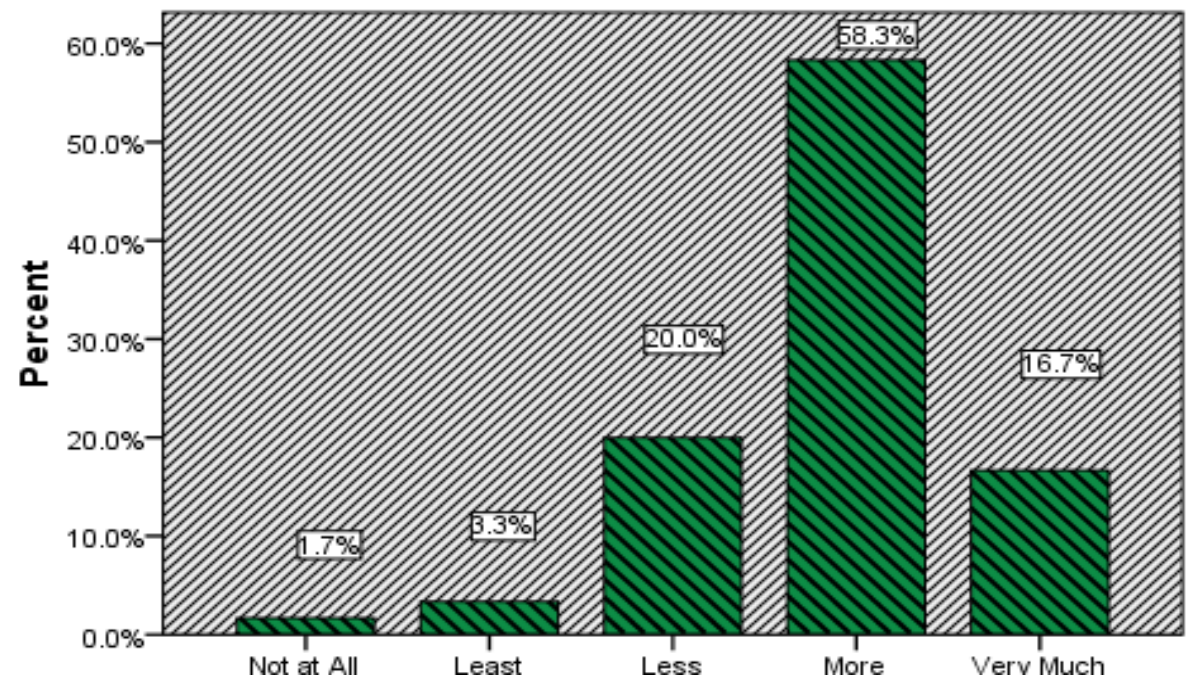

OPINION ABOUT BANK PROCEDURE

Majority of the respondents (68.3 percent) said that procedure was difficult and much complex while 31.7 percent respondents declared the procedure as easy and not much difficult altogether. 
Figure 16: Opinion about Bank Procedure

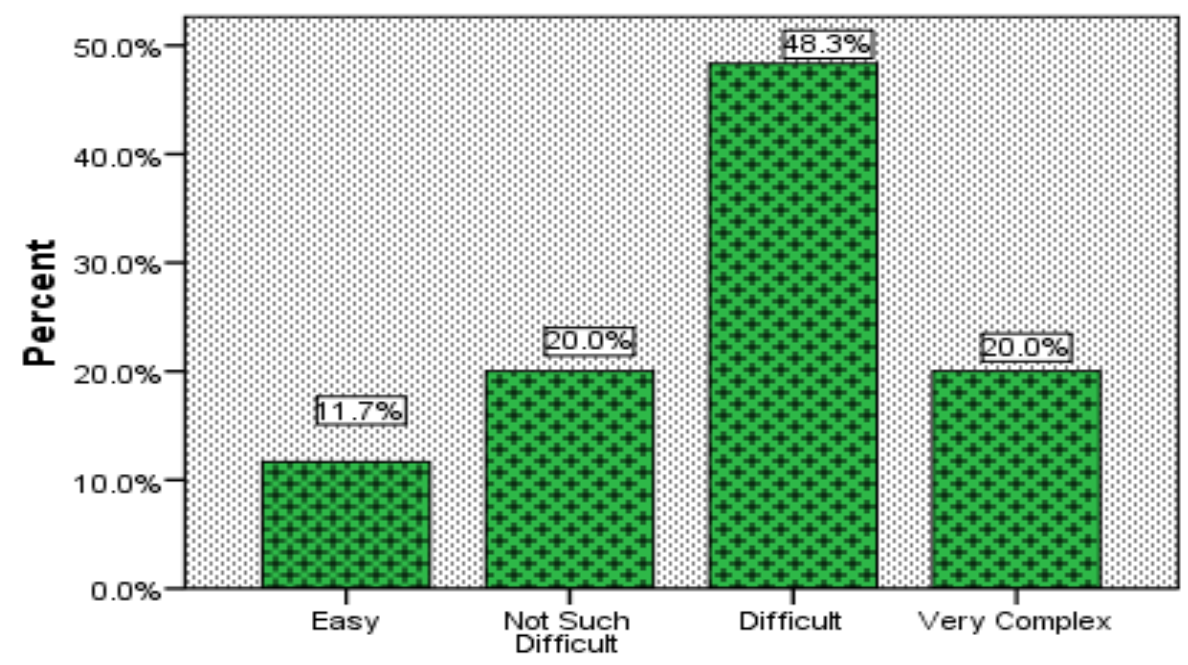

\section{CONCLUDING REMARKS AND POLICY IMPLICATIONS}

Microfinance is getting much importance in improving the living standard of the people which are neglected by formal commercial banking system. District Bahawalnagar, tehsil Minchanabad tehsil is considered as much potential market for microfinance. So it is important to know the outcome of micro financing on socioeconomic status of borrowers in Minchanabad. Primary data of 60 borrowers of NRSP bank is collected through questionnaires using Stratified random sampling technique.

The study concludes positive impact of Microfinance as a whole on socioeconomic status of borrowers. The amount of load is considered to be very low as it is from Rs. 25000 to Rs. 30000 on the average. This loan is mostly taken for agriculture purposes. Bank takes more than 10 days usually to provide loan. As a whole increase in income is observed after utilization of loan but still no any asset could be purchased. Health status, education of children, living standards and businesses are improved but no any significant employment is generated. Banks change high interest rate and procedure of applying for loan is difficult that are discouraging factor for the borrowers but rating of NRSP is high.

On the basis of above mentioned results, it may be suggested that the bank should enhance the amount of loan so that it fulfills the needs of the borrowers. The bank should start new policies to provide medium and long term loans to borrowers. Loan must 
be disbursed timely and the bank should lower its interest rate as more people can take loan from other bank. The bank should initiate training programs to guide borrowers for maximum benefits. The procedure of acquisition and recovery of amount of loan should also be made easy.

\section{REFERENCES}

Ahmad, S., Naveed, M. S., \& Ghafoor, A. (2004). Role of Micro Finance in Alleviating Rural Poverty: A Case Study of Khushhali Bank Program in Rahim Yar Khan-Pakistan. International Journal Of Agriculture \& Biology, 2, 426-428.

Akram, M., \& Hussain, I. (2011). The Role of Microfinance in uplifting Income Level:A study of District Okara -Pakistan. Interdisciplinary Journal Of Contemporary Research In Business, 2 (11), 83-94..

Alam, M., Ullah, R., Mirza, A. I., Saleem, W., Elahi, M., \& Sultan, H. (2014). Impact of Microcredit Scheme on Socio-economic Status of Farmers (A case study of PRSP in District Gujranwala). A Research Journal of South Asian Studies, 29 (1), 161169.

Asteriou, D. (2005). Applied Econometrics: A modern approach using EViews and Microfit, Palgrave Macmillan.

Ayuub, S. (2013). Impact of Microfinance on Poverty Alleviation: A Case Study of NRSP in Bahawalpur of Pakistan. International Journal of Academic Research in Accounting, Finance and Management Sciences, 3 (1), 119-135.

Brooks, C. (2013). What is Microfinance? Retrieved from: http://www.businessnewsdaily.com/4286-microfinance.html

Diro, B. A., \& Regasa, D. G. (2014). Impact of Micro Credit on the Livelihood of Borrowers: Evidence from Mekelle City, Ethiopia. International Research Journals, 3 (1), 2532.

Fareed, Z., Shahzad, F., Arshad, M., Lodhi, R. N., \& Umm-E-Amen. (2014). The Impact of Microfinance on Poverty Reduction (A case study of Okara, Southern Punjab, Pakistan). European Academic Research, 1 (10), 3196-3217.

Fayaz, M., Jan, D., Jan, A. U., \& Hussain, B. (2006). Effects Of Shortterm Creditadvanced By Ztblfor Enhancement Of Crop Productivity And Income Of Growers. Journal of Agricultural and BiologicalScience, 1 (4), 15-18.

Govt. of Pakistan (2007). Microfinance Institutions Ordinance 2001 (LV of 2001) (As amended up to 1 st July 2007). State Bank of Pakistan, 1 - 22.

Govt. of Pakistan (2013-14). Economic Survey of Pakistan, Federal Bureau of Statistics, Statistical Division.

Govt. of Pakistan (2013-14). Licencing \& Registration of Associations Not-For-Profit (Section 42 Of The Companies Ordinance, 1984). Securities and Exchange Commission of Pakistan. 1-17. 
Govt. of Punjab (2007). Multiple Indicator Cluster Survey (MICS). Bureau of Statistics, Punjab, Pakistan.

Govt. of Punjab (2008). Multiple Indicator Cluster Survey (MICS). Bureau of Statistics, Punjab, Pakistan.

Govt. of Punjab (2013). Punjab Development Statistics. Bureau of Statistics, Punjab, Pakistan.

Gujarati, D. N. and Porter, D. C. (2009). Basic Econometrics, $5^{\text {th }}$ Edition.

Hasan, K. M., Billah, M. M., Hossen, S. S., \& Mamun, T. M. (2013). Effect of Microcredit on Agricultural Output: Evidence from Rural Bangladesh. Journal of Asian Developing Studies, 2 (4), 51-61.

Imoisi, llegbinosa, A., \& Opara, G. I. (2014). Microfinance and its Impact on Poverty Alleviation: A Case Study of some Microfinance Banks in Edo State, Nigeria. American Journal of Humanities and Social Sciences, 2 (1), 27-41.

Javed, A., Luqman, M., Khan, A. S., \& Farah, A. A. (2006). Impact of Micro-credit Scheme of NRSP on the Socio-economic Conditions of Female Community in District Rawalakot, Azad Jamu and Kashmir, Pakistan. Journal Of Agriculture \& Social Sciences, 2 (3), 142-144.

Khan, M. N., Khan, M., Abassi, S. S., Anwar, S., Ali, M., \& Naheed, S. (2013). The Effect of Zarai Taraqiati Bank in Enhacing FarmProductivity through Agricultural Credit - A Case Study of District Lakki Marwat, KPK-Pakistan. Research Journal of Agriculture and Forestry Sciences, 1 (8), 1-4.

Khandker, S. R., \& Samad, H. A. (2013). Microfinance Growth and Poverty Reduction in Bangladesh: What Does the Longitudinal Data Say? Mimeo, World Bank, Washington, D.C.

Mugabi, N. (2010). Micro-credit utilization and its impact on household income: A comparative study of rural and urban areas in lganga d istrict. 1-129.

Mushtaq, R., \& Rauf, S. A. (2011). Economic impact of micro finance on borrowers: Evidence from punjab, Pakistan. SSRN, 1-21.

Nouman, M., Khan, F., \& Khattak, A. H. (2010). Availability of Microfinance \& Its Impact on Economic Growth: A Case Study of Rural Areas of Khyber Pakhtunkhwa. Journal of Managerial Sciences, 4 (2), 190-200.

Qureshi, M. I., Saleem, M. A., Khan, G. U., \& Ali, M. I. (2012). A Conceptual Framework: Role \& Impact Relationship Between Micro Finance And Poor's Access. Interdisciplinary Journal Of Contemporary Research In Business, 3 (10), 717-732.

Rahman, S. u., Hussain, A., \& Taqi, M. (2014). Impact Of Agricultural Credit On Agricultural Productivity In Pakistan: An Empirical Analysis. International Journal of Advanced Research in Management and Social Sciences, 3 (4), 125-139.

Saleem, M. A., Zaman, K. U., Khattak, B. K., \& Qureshi, M. I. (2010). Impact of Micro finance in Raising the Living Standard of People of D.I.Khan. Journal of Managerial Sciences, 5 (1), 75-83.

Shah, M. K., Khan, H., \& Khan, Z. (2008). Impact Of Agricultural Credit On Farm Productivity And Income Of Farmers In Mountainous Agriculture In Northern 
Pakistan: A Case Study Of Selected Villages In District Chitral. Sarhad Journal of Agriculture, 24 (4), 713-718.

The World Bank Group (2008). The Consultative Group to Assist the Poor (CGAP). Global Program Review, 3(1), 1 - 59.

World Bank, (2014). World Development Indicators. World Bank, Washington, DC.

Yunus, M. (2007): "Expanding Micro Credit Outreach to Reach the Millennium Development Goals Some Issues for Attention". A Paper presented at the International Seminar on Attacking Poverty with Micro Credit, Organized by PKSF in Dhaka.

i www.cgap.org

ii www.bos.gop.pk

iii www.bos.gop.pk/mics 